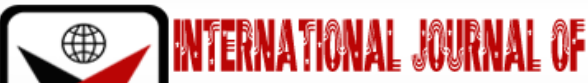

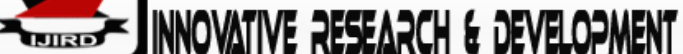

ISSN 2278-0211 (Online)

\section{Modelling Loan Accessibility among Women for Economic Development}

\author{
Amos Olaolu Adewusi \\ Senior Lecturer, Department of Estate Management, \\ Federal University of Technology, Akure, Nigeria
}

\begin{abstract}
:
The ability to start an investment is usually enabled by access to available and adequate finance. The contributions of both males and females are known to correlate with economic growth and sustainable development across countries of the world. However, in recent times, there has been growing concern about the inability of women gender to make substantial contributions to economic development despite their potentials. The paper investigates the factors that affect women's access to loan in Akure, Ondo State, Nigeria. The target population comprises of lending institutions in the study area. Data on 140 women loan applicants were purposively sourced from the databases of the selected lending institutions (commercial and microfinance banks) with forty loan applicants in the loan accessed category and one hundred of them in the loan non- accessed category. Descriptive statistics, independent $t$-test statistics and logistic regression analysis were adopted in analysing the collected data. The result of the descriptive statistics reveals that minority of the respondents had tertiary education while majority of the respondents either have no formal education or elementary education, the result of the independent $t$-test reveals that the mean values of education, income, possession of real estate as security are significantly higher in women with access to loan than women without access to loan. Furthermore, the result of logistic regression analysis reveals that applicant income, women in government work, women with tertiary education, being a married woman, year of relationship with bank and possession of collateral assets have positive significant effects on loan accessibility among women loan applicant while women in private/self-employed women, low level education, loan amount, loan duration and having history of default have inverse significant effects on women loan accessibility. Analysis of EXP $(B)$ value of variable marital status is 7 times most likely to belong to women with access to loan while EXP(B)value of women with low educational level are 15 times most likely to belong to the group of women without access to loan. For women to be more properly integrated for economic development special financing arrangement should be put in place. The findings of the current study serve as inputs for decision makers/ policymakers, and offers direction to lenders in the area of rebranding their products for an all-inclusive economic development.
\end{abstract}

Keywords: Loan, access, analysis, women, gender

\section{Introduction}

The role of women owned investment cannot be over emphasised in developing the economy of any nation (Magaisa, \& Matipira, 2017). The potentials of women for economic development can only be optimized by special and appropriate policy reforms (Vani, 2011 and Kabeer, 2020).

The overall population of women in any nation, the surpassing rate of women enterprising and loan repayment reliability are positive attributes that position women enterprises for great economic development across countries of the world (World Bank, 2013, Mukama, 2017 and Mhiche, 2020). For example, In Nigeria, female population is estimated at 80.2 million, representing 49 per cent of the total population. About 54 million of Nigeria's female population live in rural areas where they provide 60-79 per cent of the rural labour force (British Council Nigeria, 2012). Women have been found to be good in starting and growing businesses worldwide. For example, Sabah (2014) reported that in the U.S. womenowned businesses are growing at twice the rate of all firms, generating $\$ 1$ trillion in sales, and employing more than 7 million workers. Women in Canada hold ownership in 47 percent of small enterprises and accounted for 70 percent of new business start-ups in 2013. In China, more than 1,000 employees and engaged in women own small businesses. Women are starting businesses at a faster rate than men, and are making significant contributions to job creation and economic growth (Global Partnership for Financial Inclusion, 2011; Ahmad \&Muhammad, 2015; Bullough, et al, 2017 and Korosteleva and Stępień-Baig, 2020).

The same is true for transition economies, although the comparable rate of growth is slower. In Indonesia, 2007 data showed that women-owned businesses grew at 8 per cent, while men-owned businesses shrank to 0.3 per cent. In Thailand, women-owned businesses grew by 2.3 per cent while the male counterparts grew only by 0.3 percent (Nwosu, Orji, Nnetu, \& Nwangwu, 2015). It is a known fact that improving financial support for women would increase the number 
of new businesses, which in turn would boost economic activity, enable the expansion of old businesses and leading to increased productivity and growth (Megan, 2005 and Kulb, Hennink, Kiiti, \& Mutinda, (2016).

Aside from women potentials as stated above, the experience of the Grameen Bank of Bangladesh as reported by Karim (2008) suggests that women might be better fund managers. Of all loans advanced to women by the bank, over 98 per cent were recovered, implying a near 0 per cent default. Fund providers are beginning to consider giving women access to finance as a lucrative and worthwhile business. The Global Banking Alliance for women has seen a steady upward trend in its profits, which has also put its operations on the path to sustainability (Ngozi, 2002). According to Ifelunini and Wosowei, (2013), as poor women are increasingly recognized to be better borrowers, they are starting to become of interest also to regular financial institutions. But despite the proven positive impact of providing microfinance services to female entrepreneurs, there are still great barriers in accessing microfinance by women entrepreneurs (Innocent and Elizabeth, 2013 and De Haan, 2016). Sanusi, (2012) opined that such barriers include: lack of ownership of collateral, this is more pronounced in traditions which preclude women from right to own property; absence of credit histories, the fact that most women businesses are informally organized, educational status of women, perception of women to credit facilities etc. The ability of women to play this role effectively depends on how far the society supports their development in terms of access to funds.

When women are economically empowered through access to finance, they will be able to acquire assets for increased economic activity. The empowerment will invariably increase their household/family well-being through improved nutrition, health, literacy and happiness (Amuta, 2013). Women's increase in economic activities and then increased decision-making leads to a wider social and political empowerment (FA0, 2013). Access to finance by women entrepreneurs remains a daunting task despite the pivotal role of women in the economy (Ifelumi \& Wosowei, 2013).

It is worthy of note that despite a growing number of policies and programs that are arising to address the needs of the growing number of women business owners and their enterprises worldwide, access to finance is still the single biggest obstacle facing most women entrepreneurs. The evidence presented in the literature shows that limited access to credit by women is often interpreted too easily as a loan supply-side problem but it is more of the demand side. Studies have shown that women are not being discriminated against in having access to credit facilities rather, most times there is a lack of loan demand by women entrepreneurs (Suzi and Lisa, 2011 and Chudi, 2013), this was also corroborated by Sanusi, (2009), the reason few women participated in the program was due more to the fact that there were few women applicants rather than to a more frequent rejection of women applicants than men indiscriminately.

It is pertinent to note that though there is a growing women participation in a credit transaction, a good number of them are yet to enjoy credit facilities being provided by governmental agencies and non-governmental organizations. The question that arises from the foregoing is, what factors distinguish women with access to loans from those without access to loans? Therefore, this paper investigates the factors that affect loan accessibility among women in Nigerian lending institutions.

The paper is structured as follows; the background introduction is captured in the first section of this paper, the second section discusses literature, the third section centers on the methodology followed by empirical results, a summary of findings, and conclusion in that order.

\section{Review of Related Literature}

\subsection{An Overview of Female Gender in Credit Facility}

Several studies have been carried out to establish the extent to which access to microfinance by women can help in poverty alleviation, women's empowerment, and sustainable development of the society and the country's economy at large. Amongst the available studies are Ebdon (1995), Rahman (1999), and Mayoux (1999, 2000). Leach and Sitaram (2002) highlighted the reasons why women should be provided with loans to fund their businesses. Among others, firstly, it is argued that women are disproportionately represented amongst the poorest in society and require help as compared to men, as far as securing sustainable livelihoods is concerned. Secondly, women are discriminated against in the formal labor market, so they end up looking for other sources of income within the informal sector. Thirdly, it is also argued that women-headed households are on the increase as a result of economic recession, changing labor needs, increasing urbanization, and the break-up of extended family structures. Women have therefore become the breadwinners in some families. Women-headed households being more vulnerable than male-headed ones is advanced as the fourth reason. It is argued that such households are more vulnerable in times of crisis as they have fewer resources to draw from.

Mayoux (1999) suggest that repayment rates on loans and contributions to family well-being are often higher among women than among men. Thus, implying there would be no basis to screen women borrower along the lines of risk of repayment. A study by Mayoux (2000) indicates some basic views on the link between microfinance and women's empowerment. The author advocates of the positive link between microfinance credit and women's empowerment suggest the financial self-sustainability paradigm, the poverty alleviation paradigm, and the feminist empowerment paradigm.Hisrich and Brush (1987) opine that the perception that formal financial institutions discriminate against women is also pervasive in developed countries. They observed that a large literature treats the issue of bank discrimination against female business owners in western countries, but the measurement of discrimination is largely based on subjective perceptions and lacks statistical evidence.

\subsection{Financial Availability and Accessibility}

Access to finance refers to the possibility that individuals or enterprises can access financial services, including credit, deposit, payment, insurance, and other risk management services (Demirgüç-Kunt, Beck \& Honohan, 2008). 
However, the lack of it limits the range of services and credits accessible to households and enterprises. Poor individuals and small enterprises need to rely on their wealth or internal resources to invest in their education and businesses, which limits their full potential and leading to the cycle of persistent inequality and diminished growth (World Bank and GFDR, 2014). Financial availability and accessibility are cited in many studies as being one of the major barriers and constraints to growth. Chinasa (2015) reported that at a 'Kenya Gender and Economic Growth Assessment in May 2006, a case clearly illustrating the plight of women was presented by an official from the Ministry of Trade and Industry. A loan approved for the woman applicant by the Joint Loan Scheme at the Ministry failed to materialize because her husband refused to pledge the family's land title deeds as collateral. Owning title deeds as collateral to finance expansion is still a hurdle for most women entrepreneurs, given that property is not usually registered in their names (Kabukuru,2016), Mwayi, Odindo \& Odindo, 2015). The Government is, however, moving towards solving this problem through the Sessional Paper No. 2 of 2005 and the Micro-Finance Bill of 2005. The latter became an Act of Parliament in December 2006. Accessibility to initial capital, even when available, is also a major hurdle for women entrepreneurs.

\subsection{Women Access to Credit Facility and Microfinance Programs}

The reality of women's lower education, skill level, and work experience may lessen their attractiveness to lenders. Many banks' marketing strategies are built around a client profile that might not fit women entrepreneurs (the ability to access banks' outlets or the ability to be available during standard opening hours can be cited as examples). Culturally driven constraints faced by women entrepreneurs, such as their mobility and higher demands on their time, may further limit their ability to access finance (GPFI, 2011).

Women generally lack knowledge of the financial options available to them. Furthermore, the cost of getting this information (measured in money, time, and energy) may be high due to family responsibilities (Sanusi, 2012). Poor women in rural and urban areas work longer hours than men, spend more time on unpaid care work and subsistence agriculture, and have less time to engage in paid work and social and cultural activities (Mthethwa, 2016). Despite this amount of time women put into work, they earn little, own no assets, and have no forms of security to handle social shocks. This situation is common to both urban and rural communities in Nigeria. Nevertheless, in some countries, few or no institutions offer financial services under terms and conditions that are favorable to women (Sanusi, 2009). These findings confirm that the type of products offered, their conditions of access, and the distribution of an institution's portfolio among different products and services affect women's perception about access to financial services.

The activities of microfinance institutions (MFIs) in providing women access to finance cannot be overemphasized. Cheston and Kuhn, (2002) reported that about 14.2 million of the world's poorest women now have access to financial services through specialized MFIs, banks, NGOs, and other nonbank financial institutions. The poor women account for not less than 74 percent of the 19.3 million of the world's poorest people, who are now being served by microfinance institutions. With this access, most of them can invest in businesses that they own and operate themselves. Contrary to conventional wisdom, the vast majority of them have excellent loan repayment records, despite the daily hardships they face; they have shown that it is a very good idea to lend to the poor and to women.

Fay and Williams (1993) observed that the microfinance industry has made great strides toward identifying barriers to women's access to financial services and developing ways to overcome those barriers. A 2001 survey by the Special Unit on Microfinance of the United Nations Capital Development Fund (SUM/UNCDF) of 29 microfinance institutions revealed that approximately 60 percent of these institutions' clients were women. Six of the 29 focused entirely on women. Among the remaining 23 mixed-sex programs, 52 percent of clients were women. The study also showed, however, that those programs offering only individual loans or relatively high minimum loan amounts tended to have lower percentages of women clients, thus affirming the importance of designing appropriate products for women.

According to (USAID, 2000), approximately 70 percent of USAID-supported MFIs' clients were women. Considerable variation among the regions was seen, however, with percentages of women clients ranging from 27 percent in the Near East to 87 percent in Asia. In Eastern Europe, where USAID has traditionally supported individual-lending programs, the percentage of women clients dropped as low as 48 percent in 1999 before rising to 54 percent in 2000 when USAID began to support more group-lending programs offering smaller loans.

Although the UNCDF study found that larger programs tended to have lower percentages of women clients, data collected by the Microcredit Summit Campaign found no statistically significant correlation between the numbers of very poor clients served by each institution and the percentage of those clients who were women. Microfinance institutions around the world have been quite creative in developing products and services that avoid barriers that have traditionally kept women from accessing formal financial services such as collateral requirements, male or salaried guarantor requirements, documentation requirements, cultural barriers, limited mobility and literacy (GPFI, 2011).

Although women's access to financial services is on the increase in the past ten years, yet their level of benefit cannot be compared to that of males. Some MFIs are providing a decreasing percentage of loans to women, despite their growing capacity to do better; in some cases, loan sizes made available to women are smaller than those of men, even when they are in the same credit program, the same lending group and the same community (Cheston \& Kuhn, 2002). Some differences in loan sizes may be a result of women's greater poverty or the limited capacity of women's businesses to absorb capital (World Bank, 2013). Microfinance institutions (MFIs) and commercial banks choose where they locate, thus excluding entrepreneurs in remote regions, leading to regional disparities. Credit conditions when forming a group, paying membership fees, group registration fees and joining saving plans, result in delays in accessing initial capital, thereby worsening the women's household financial burden (Stevenson \& St-Onge, 2005). However, this is no longer the key barrier and constraint, but a lack of creativity, innovativeness, and responsiveness (on the part of capital suppliers) that now hampers women's entrepreneurship in Africa. Whereas many MFIs emerged to provide initial and working capital, 
relevance and cost-effectiveness are often inappropriate in satisfying the particular needs of potential and operating women entrepreneurs (Mbiti, Mukulu, Mung'atu, \& Kyalo 2015).

\section{Research Methodology}

\subsection{Data Sources and Collection}

The study was carried out in Akure, the capital city of Ondo State, Nigeria. The target population for the study includes women entrepreneurs and lending institutions in the study area. A total of 399 questionnaires were randomly distributed to women in business in Akure, a total of 352 were retrieved, and 337 were properly filled and found useful for analysis, representing 84\% while 147 loan accounts were purposively accessed from the databases of some selected lending institutions. The women applicants' accounts were categorized into women with access to loans and women without access to the loan. Out of 147 women loan applicants, 60 of them had no access to loans as their applications were not approved while 87 of them had access to loans. Data were collected on 17 variables as follows: Age of Applicant, Selfemployed occupational status, Civil servant occupational status, Primary Education, Secondary, Education, Tertiary Education, Applicant's Marital Status, Loan Duration, History of Default, Agricultural purpose, Trading purpose, guarantee as collateral, Land as collateral, Building as collateral, Possession of Certificate of Occupancy, Year of Banking Relationship and Applicant's Income. Data for the study were sourced from the databases of five (5) commercial banks and three (3) microfinance banks in Akure, Ondo state Nigeria.

The target population for the study comprised of women entrepreneurs and lending institutions in the study area. For the population of the women entrepreneur, 300 questionnaires were randomly administered on the women entrepreneur to elicit socio-economic information of the women entrepreneur. This information, includes the age of the applicant, educational qualification of the applicant, occupational status. On the population of the lending institutions, data were sourced from the databases of five commercial banks and three microfinance banks in the study area. Fillable spreadsheet forms were sent to the participating financial institutions to elicit information on the women applicants for which loan was eventually approved and women applicants for which access to the loan was denied. The lending institution returned 40 women loan applicants that had access to loan and 100 women loan applicants that did not have access to loans. A total of 140 loan applicants were gathered from all 8 commercial and microfinance banks. The number of loan applicants appears small, this may be because most lending institutions do not positively dispose to disclosing clients' information to the third party, although the information required from lending institutions are such that do not reveal borrowers' details. However, few lending institutions volunteered to participate in the survey. The fewness of the data collected did not affect the findings of the paper. The fillable spreadsheet forms contain such information as, age, applicant's income, occupation, level of education, marital status, loan amount, loan duration, history of default, acceptable collateral ranging from possession of a certificate of occupancy, guarantee, salary, land, building and years of relationship with the financial institutions.

\subsection{Variable Description}

One dependent variable and seventeen independent variables were examined. The dependent variable (loan accessibility) was measured as a dummy variable coded 1 for access to loan and 0 for non-access to loan. Most of the variables were measured as dummy except age, years of relationship with the bank, loan duration, and loan amount as contained in table 1.

\begin{tabular}{|c|c|c|c|}
\hline $\mathbf{S} / \mathbf{N}$ & Code & Description & Measurement \\
\hline 1 & LACC & Loan accessibility & 1 for accessed, 0 if otherwise \\
\hline 2 & AGEA & Age of applicant & Actual number in years \\
\hline 3 & APLY & Applicant income & Actual amount in Naira \\
\hline 4 & GOTW & Government work as occupation & 1 if engaged in government work, 0 if otherwise \\
\hline 5 & PRVW & Private work as occupation & 1 if private or self-employment, 0 if otherwise \\
\hline 6 & EDUCT 1 & No formal education & 1 for no formal education, 0 if otherwise \\
\hline 7 & EDUCT 2 & Primary education only & 1 for primary education only, 0 if otherwise \\
\hline 8 & EDUCT 3 & $\begin{array}{c}\text { Primary and Secondary education } \\
\text { only }\end{array}$ & $\begin{array}{c}1 \text { for primary and secondary education, } 0 \text { if } \\
\text { otherwise }\end{array}$ \\
\hline 9 & EDUCT 4 & Tertiary education & 1 for tertiary education, 0 for otherwise \\
\hline 10 & MARTS & Marital status & 1 if ever married, 0 if otherwise \\
\hline 11 & LOAMT & Loan amount & Actual amount in Naira \\
\hline 12 & LOAND & Loan duration & Actual numbers in years \\
\hline 13 & PRVDF & Previous default & 1 if no previous default, 0 if otherwise \\
\hline 14 & COOC & $\begin{array}{c}\text { Certificate of occupancy as } \\
\text { collateral }\end{array}$ & 1 if available, 0 if otherwise \\
\hline 15 & GUARTC & Guarantee as collateral & 1 if guarantee is taken as collateral, 0 if otherwise \\
\hline 16 & SALRC & Salary as collateral & 1 if salary is offered as collateral, 0 if otherwise \\
\hline 18 & LNBGC & Land and building as collateral & $\begin{array}{l}1 \text { if land and building are offered as collateral, } 0 \text { if } \\
\text { otherwise }\end{array}$ \\
\hline
\end{tabular}

Table 1: Variable Description and Measurements 


\subsection{Tool of Analysis}

Descriptive statistics were adopted to analyze the socio-economic characteristics of the women entrepreneur, independent T-test statistics were used to determine the areas of difference between the loan accessed and non-loan accessed groups, while logistic regression analysis was used to identify the effect of the predictor variables on the response (dependent) variable.

Binary regression is used in the study; the choice of this tool is on the basis that the response (dependent) variable is dichotomous. The dependent variable in this study is loan accessibility which is measured as 1 for women with access to loan and 0 for women without access to the loan.

It is necessary to model log odds as a linear function of the explanatory variable

Logit $(\mathrm{Y})=\operatorname{Ln}($ odds $)=\operatorname{Ln}(\mathrm{p} / 1-\mathrm{p})=\alpha+{ }^{\beta} \mathrm{X} \ldots . .(1)$

Where $\mathrm{p}$ is the probability of interested outcome and $\mathrm{x}$ is the explanatory variable while $\alpha$ and $\beta$ are the logistic regression parameters

A change in the independent variable produces a change in the probability of being in a category (women with access to loan or women without access to loan).

The predicted probability for each case can be derived from the log odds and consequently the residual can be calculated (kwofie, owusu-Ansah, and Boadi, 2015). The logistic regression in this regard was used to calculate the probability of belonging to one of the groups.

\section{Data Presentation and Discussion of Results}

Data analysis is presented in tables and discussions are structured in line with the objective of the study

\begin{tabular}{|c|c|c|c|c|}
\hline Marital Status & Number & Total & $\mathbf{\%}$ & \\
\hline Married but Single & 45 & & 32.14 & \\
\hline Married & 55 & & 39.29 & \\
\hline Widow & 25 & & 17.86 & \\
\hline Single & 15 & 140 & 10.71 & 100 \\
\hline Education & & & & \\
\hline No Formal Education & 40 & & 28.57 & \\
\hline Primary Education Only & 60 & & 42.86 & \\
\hline Primary and Secondary & 30 & & 21.43 & \\
\hline Tertiary & 10 & 140 & 7.14 & 100 \\
\hline Accessibility & & & & \\
\hline Yes & 40 & & 28.57 & \\
\hline No & 100 & 140 & 71.43 & 100 \\
\hline
\end{tabular}

Table 2: Demographic Characteristics of Sampled Women Loan Applicants

Table 1 shows the marital, educational, and loan accessibility status of the sampled women loan accounts. On marital status, the cumulative percentage of women not in a marriage relationship with any man is greater than those that are the married, indicating that except such women are financially empowered under special arrangements their dreams of accessing loan under the current stringent conditionality obtainable in the formal loan markets will remain unachievable. Also, the table shows the educational status of the sampled women, only $7.14 \%$ of the sampled women have tertiary education while the majority of women sampled have either no former education, primary education only, or primary/ secondary education. This corroborates the assertion of Mukama (2017) that low literacy level affects loan accessibility, yet their contributions to the development of the economy are significant, hence the need to specially design finance arrangements that could give them access to financial support.

\subsection{Characteristics of Women with Access to Loans and Women without Access to a Loan}

The succeeding section presents an analysis of the independent t-test based on the result of the Levene test.

\begin{tabular}{|l|l|l|l|l|l|l|l|}
\hline & \multicolumn{2}{|c|}{$\begin{array}{c}\text { Without Access } \\
\text { N=100 }\end{array}$} & \multicolumn{2}{c|}{$\begin{array}{c}\text { With Access } \\
\text { N=40 }\end{array}$} & \multicolumn{4}{c|}{ T-test Statistics } \\
\hline Variables & SD & mean & SD & mean & MD & t & Sig.(2-tailed) \\
\hline Age of Applicant & 11.301 & 42.43 & 8.774 & 40.71 & 1.712 & 0.987 & 0.326 \\
\hline Self Employed & 0.300 & 0.13 & 0.187 & 0.04 & 0.098 & 2.001 & $0.048^{* *}$ \\
\hline Civil Servant & 0.243 & 0.43 & 0.346 & 0.56 & 0.834 & 1.848 & $0.050^{* *}$ \\
\hline No formal Education & 0.453 & 0.57 & 0.436 & 0.25 & 0.183 & 2.288 & $0.030^{* *}$ \\
\hline Primary Education Only & 0.343 & 0.13 & 0.187 & 0.04 & 0.098 & 2.004 & $0.048^{* *}$ \\
\hline $\begin{array}{l}\text { Primary and Secondary } \\
\text { Education only }\end{array}$ & 0.462 & 0.3 & 0.413 & 0.21 & 0.086 & 1.147 & $0.0254^{* *}$ \\
\hline Tertiary Education & 0.5 & 0.57 & 0.436 & 0.75 & 0.183 & 2.288 & $0.024^{* *}$ \\
\hline Applicant's Marital Status & 0.486 & 0.63 & 0.385 & 0.82 & 0.188 & 2.491 & $0.001^{* * *}$ \\
\hline
\end{tabular}




\begin{tabular}{|l|l|l|l|l|l|l|l|}
\hline & \multicolumn{2}{|c|}{$\begin{array}{c}\text { Without Access } \\
\text { N=100 }\end{array}$} & \multicolumn{2}{c|}{$\begin{array}{c}\text { With Access } \\
\text { N=40 }\end{array}$} & \multicolumn{4}{c|}{ T-test Statistics } \\
\hline Loan Duration & 12.124 & 27.47 & 11.19 & 28.36 & 0.89 & 0.455 & 0.65 \\
\hline History of Default & 0.403 & 0.2 & 0.214 & 0.05 & 0.152 & 2.67 & $0.009^{* *}$ \\
\hline Possession of C of O & 0.279 & 0.08 & 0.364 & 0.15 & 0.071 & 1.333 & $0.03^{* *}$ \\
\hline Guarantee as Collateral & 0.243 & 0.43 & 0.346 & 0.56 & 0.834 & 1.848 & $0.050^{* *}$ \\
\hline Salary as Collateral & 0.494 & 0.40 & 0.496 & 0.42 & 0.017 & 0.199 & 0.842 \\
\hline $\begin{array}{l}\text { Land and Building as } \\
\text { Collateral }\end{array}$ & 0.179 & 0.8 & 0.364 & 0.15 & 0.071 & 1.333 & $0.03^{* *}$ \\
\hline Year of Banking Relationship & 5.211 & 5.4 & 5.318 & 6.2 & 0.802 & 0.9 & 0.37 \\
\hline Applicant's Income & 0.329 & 0.52 & 0.425 & 0.92 & 1.101 & 2.293 & $0.025^{* *}$ \\
\hline
\end{tabular}

Table 2: Characteristics of Women with Access to Loan and Women without Access to Loan (T-Test Statistics)

${ }^{* * *}$ ) significant at $p \leq 0.01$ (99.0\% confidence level)

${ }^{* *}$ ) significant at $p \leq 0.05$ (95\%confidence level)

$\left({ }^{*}\right)$ significant at $p \leq 0.1$ ( $90 \%$ confidence level)

$N=$ total population

Variable ${ }^{1}=t$-test based on 'Equal variances assumed' as indicated in the Levene's Test when $F$ is not significant at 0.05 level. Variable $^{2}=t$-test based on 'Equal variances not assumed' as indicated in the Levene's Test when F is significant at 0.05 level.

Table 2 presents the result of the unpaired (independent) t-test used in comparing the characteristics of the sampled women in the two categories. The table shows that marital status (being married) is significantly higher in the people with access to loan category than in the people with no access category at $p \leq 0.01$, indicating that married women may have better access to loan than the unmarried. The mean value of building as collateral for a loan is also significantly higher in women with access to loan category at $\mathrm{p} \leq 0.01$, showing that where real estate is required as a collateral asset, people who possess building have more access to the loan facility. The result of the t-test reveals that women with selfemployed occupational status are significantly higher in women without access to a loan at $p \leq 0.05$ than in the category of women with access to loan,

The test also indicates that women with no formal education, only primary education are significantly higher in women without access to a loan at $\mathrm{p} \leq 0.05$ than in the category of women with access to loan, indicating that low literacy status could account for the reason why most women do not have access to a loan. On the other hand, the mean value of tertiary education is significantly higher in women with access to loan category at $p \leq 0.05$ than in the category of women without access to loan, indicating that women with higher education stand better chances of accessing the loan. The income level of the applicants is also significantly higher in the category of people with loan access than people with no access category at $\mathrm{p} \leq 0.05$, indicating that a high- and stable-income level influence loan accessibility.

Furthermore, the history of default is significantly higher in the category of women without access to loan than women with access to loan category, at $\mathrm{p} \leq 0.1$, this shows that previous default hinders loan accessibility. Also, the use of guarantee and salary as collateral for the loan is significantly higher in women with access to loans than women without access to the loan. It thus means that access to the loan is facilitated when women have somebody that could guarantee them.

\subsection{Effect of Factors That Influence Loan Accessibility in Lending Institutions in Akure}

The logistic regression was adopted to determine the relationship between the dependent and independent variables, the succeeding section discusses the necessary tests to ascertain the fitness of the model. In order to test the fitness of the model, the probability of the observed results given the parameter estimates known as the likelihood must be explained. Since the likelihood is a small number, usually less than 1, it is customary to use -2Log likelihood (-2LL) as an estimate of how well the model fits the data. Table 3 presents the data;

\begin{tabular}{|c|c|c|c|}
\hline \multicolumn{2}{|c|}{ Iteration } & $\mathbf{- 2}$ Log Likelihood & Coefficients \\
\cline { 3 - 4 } & & & Constant \\
\hline Step 0 & 1 & 195.608 & .333 \\
\cline { 2 - 4 } & 2 & 195.608 & .336 \\
\cline { 2 - 4 } & 3 & 195.608 & .336 \\
\hline \multicolumn{3}{|c|}{ a. Constant is included in the model. } \\
\hline \multicolumn{3}{|c|}{ b. Initial -2 Log Likelihood: 195.608 } \\
\hline c. Estimation terminated at iteration number 3 because parameter \\
estimates changed by less than .001. \\
\hline
\end{tabular}

Table 3 presents the initial model summary which indicates that -2Log likelihood estimate is 195.608 . Ordinarily, testing for goodness-of-fit using -2log likelihood test (-2LL) should reveal a very low value for adequacy; however, the present -2Likelihood of 195.608 was based on constant only. 


\begin{tabular}{|c|c|c|c|c|}
\hline & & Chi-square & df & Sig. \\
\hline \multirow{3}{*}{ Step 1 } & Step & 84.969 & 21 & .000 \\
\cline { 2 - 5 } & Block & 84.969 & 21 & .000 \\
\cline { 2 - 5 } & Model & 84.969 & 21 & .000 \\
\hline
\end{tabular}

Table 4: Omnibus Tests of Model Coefficients

Hosmer and Lemeshow (2002) assert that if the second model which consists of constant and predictors result in significant reduction in the -2LL, then the goodness-of-fit is adequate. The difference between -2LL for the two models with the difference in the degree of freedom has a chi-square distribution of 84.961 as indicated in Table 4 .

\begin{tabular}{|c|c|c|}
\hline Chi-square & Df & Sig. \\
\hline 7.213 & 8 & .514 \\
\hline
\end{tabular}

Table 5: Hosmer and Lemeshow Test

\begin{tabular}{|c|c|c|c|c|c|}
\hline \multirow{2}{*}{\multicolumn{3}{|c|}{ Observed }} & \multirow{2}{*}{\multicolumn{3}{|c|}{ Predicted }} \\
\hline & & & \multirow{2}{*}{\multicolumn{2}{|c|}{ Access to Loan }} & \\
\hline & & & & & \multirow{2}{*}{$\begin{array}{c}\text { Percentage } \\
\text { Correct }\end{array}$} \\
\hline & & & no access & access to loan & \\
\hline \multirow[t]{3}{*}{ Step 0} & \multirow[t]{2}{*}{ access to loan } & no access & 0 & 100 & .0 \\
\hline & & access to loan & 0 & 40 & 100.0 \\
\hline & \multicolumn{2}{|c|}{ Overall Percentage } & & & 58.3 \\
\hline
\end{tabular}

Table 6: Classification Table ${ }^{a, b}$

a. Constant is Included in the Model

b. The Cut Value Is .500

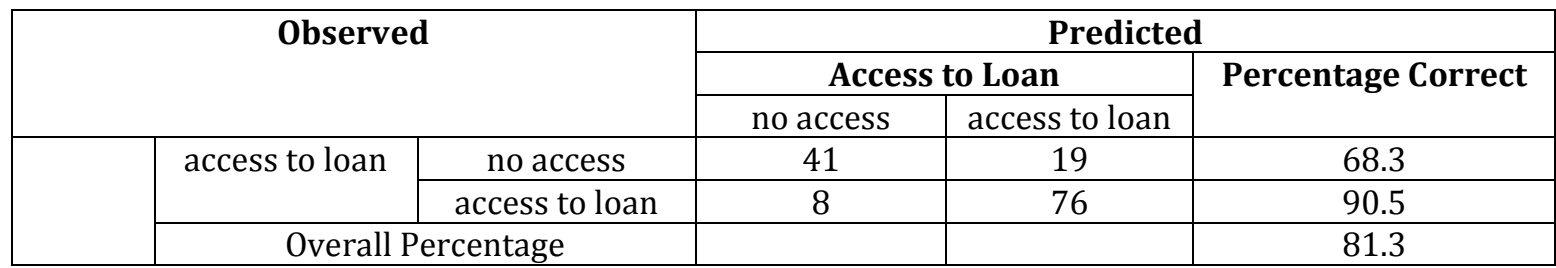

Table 7: Classification Tablea

a. The Cut Value is .500

\begin{tabular}{|c|c|c|c|}
\hline Step & -2 Log Likelihood & Cox \& Snell R Square & Nagel kerke R Square \\
\hline 1 & $110.638^{a}$ & .446 & .600 \\
\hline
\end{tabular}

Table 8: Model Summary

a. Estimation Terminated at Iteration Number 20 Because Maximum Iterations Has Been Reached

The chi-square figure for the new block added in the second model shows a reduction in the -2LL of the constant by 84.961 as shown by the Omnibus test in Table 3 when all the predictors' variables are added which is also significant at $\mathrm{p} \leq 0.00$. Using the $-2 \mathrm{LL}$, the goodness-of-fit of our model is adequate since the difference in the two model results in a significant reduction of -2log likelihood. This increases the predictive power of the Logistic Regression Model from 58.3\% to $81.3 \%$ which is satisfactory as shown in Tables 6 and 7. The next step of goodness-of-fit is $\mathrm{R}^{2}$ indices defined by Cox and Snell (1989) and Nagel Kerke (1991) which is seen from Table 8, the values of Cox and Snell (0.446) and Nagel Kerke $(0.600)$ suggest that the model is adequate as slight variation is observed between the two values.

The Hosmer and Lemeshow test which is used for testing the hypothesis that 'there is no significant difference between male accessibility and female accessibility to loan in lending institutions in Akure', reveals that this null hypothesis is acceptable since the level of significance (0.514) attained as seen in table 5 is greater than 0.05 (with $95 \%$ confidence level) to disregard the alternative hypothesis that 'there is a significant difference between women with access to loan and women without access to a loan in lending institutions in Akure.

Equation 1 below represents the predictive probability model generated by the Logistic Regression Model from where coefficients of independent variables, odd ratio, and effects of each of the predictor variables were generated as contained in table 9.

$\mathrm{LA}=-0.064 \mathrm{X}_{1}+0.381 \mathrm{X}_{2}+0.175 \mathrm{X}_{3}-0.600 \mathrm{X}_{4}-2.736 \mathrm{X}_{5}+1.601 \mathrm{X}_{6}+2.002 \mathrm{X}_{7}-1.470 \mathrm{X}_{8}-0.052 \mathrm{X}_{9}-$

$0.758 \mathrm{X}_{10}+2.421 \mathrm{X}_{11}+2.346 \mathrm{X}_{12}+2.768 \mathrm{X}_{13}+2.351 \mathrm{X}_{14}+0.154 \mathrm{X}_{15}-0.412$ equation 1 


\begin{tabular}{|c|c|c|c|c|c|c|}
\hline Variables & B & S.E. & Wald & Df & Sig. & $\operatorname{Exp(B)}$ \\
\hline Age $\left(\mathrm{X}_{1}\right)$ & -0.064 & 0.034 & 3.517 & 1 & 0.061 & 1.066 \\
\hline Applicant's income $\left(\mathrm{X}_{2}\right)$ & 0.381 & 0.364 & 1.086 & 1 & $0.003^{* * *}$ & 1.461 \\
\hline $\begin{array}{c}\text { Government work as } \\
\text { occupation }\left(\mathrm{X}_{3}\right)\end{array}$ & 0.175 & 0.966 & 0.033 & 1 & $0.050^{* *}$ & 1.191 \\
\hline $\begin{array}{l}\text { Private Work as } \\
\text { occupation }\left(\mathrm{X}_{4}\right)\end{array}$ & -0.600 & 0.724 & 0.625 & 1 & $0.032^{* *}$ & 1.822 \\
\hline $\begin{array}{l}\text { Primary / Secondary } \\
\text { education only }\left(\mathrm{X}_{5}\right)\end{array}$ & -2.736 & 1.533 & 3.185 & 1 & $0.074^{*}$ & 15.422 \\
\hline Tertiary Education $\left(\mathrm{X}_{6}\right)$ & 1.601 & 0.814 & 0.544 & 1 & $0.0461^{* *}$ & 4.957 \\
\hline Marital status $\left(\mathrm{X}_{7}\right)$ & 2.002 & .651 & 9.457 & 1 & $0.002^{* * *}$ & 7.403 \\
\hline Loan Amount $\left(\mathrm{X}_{8}\right)$ & -1.470 & 0.700 & 4.443 & 1 & $0.035^{* *}$ & 4.349 \\
\hline Loan Duration $\left(\mathrm{X}_{9}\right)$ & -0.052 & 0.038 & 1.877 & 1 & 0.171 & 1.053 \\
\hline $\begin{array}{l}\text { Previous History of } \\
\text { Default }\left(\mathrm{X}_{10}\right)\end{array}$ & -0.758 & 0.891 & 0.724 & 1 & $0.034^{* *}$ & 2.134 \\
\hline $\begin{array}{c}\text { Certificate of occupancy } \\
\text { as collateral }\left(\mathrm{X}_{11}\right)\end{array}$ & 2.421 & 1.331 & .022 & 1 & $.000^{* * *}$ & 11.257 \\
\hline $\begin{array}{c}\text { Guarantee as } \\
\text { Collateral }\left(\mathrm{X}_{12}\right) \\
\end{array}$ & 2.346 & 1.321 & 3.153 & 1 & $0.032^{* *}$ & 14.235 \\
\hline Salary as collateral $\left(\mathrm{X}_{13}\right)$ & 2.768 & 1.391 & 3.957 & 1 & $0.047^{* *}$ & 15.927 \\
\hline $\begin{array}{c}\text { Land and building as } \\
\text { collateral }\left(\mathrm{X}_{14}\right)\end{array}$ & 2.351 & 1.451 & 3.167 & 1 & $0.022^{* *}$ & 10.496 \\
\hline $\begin{array}{l}\text { Years of Relationship } \\
\text { with bank }\left(\mathrm{X}_{15}\right)\end{array}$ & 0.154 & 0.081 & 0.451 & 1 & $0.050^{* *}$ & 1.166 \\
\hline Constant & -0.412 & 0.701 & 0.042 & 1 & 0.043 & 1.509 \\
\hline
\end{tabular}

Table 9: Result of Logistic Regression Analysis

\subsection{Empirical Analysis}

Table 9 presents the logit regression result showing the coefficient $\beta$ of the independent variable, significance, and odds ratio.

The contributions of seventeen independent variables to the dependent variable were examined. Under the significance level of $\mathrm{p} \leq 0.000$, the influencing variables include, applicant's income, marital status, and possessing a certificate of occupancy as collateral, under the significance level of $p \leq 0.05$, the influencing variables are, government work as an occupation, private work as an occupation, tertiary education, loan amount, previous loan default, guarantee as collateral, salary as collateral and years of relationship with the bank. Also, primary and secondary education were significant at $\mathrm{p} \leq 0.1$, while other factors such as loan duration and age showed no significance to the dependent variable.

On the direction of influence of explanatory variable on the response variable, applicant's income, work as an occupation, tertiary education, marital status, possession of a certificate of occupancy as collateral, and year of relationship with banks have significant positive effects on loan accessibility. It was also revealed that private work as an occupation, primary and secondary education only, loan amount, loan duration, and previous default have significant negative effects on loan accessibility among women.

Furthermore, the livelihood of belonging to one group or the other was also examined using the EXP (B) column in table 9. If the value of $\operatorname{EXP}(B)$ exceeds 1, then, the odds of an outcome occurring increases, while if the figure is less than 1 then any increase in the predictor leads to a drop in the odds of the outcome occurring (Kwofie et al,2015). For example, the EXP(B) value associated with the applicant's income is 1.461, which means that when the applicant's income is raised by one unit, the odd ratio is 1.461 times likely to belong to the loan accessed group, the EXP(B) value associated with marital status is 7.403 which means that a change in marital status will increase the odds ratio by 7.403 times likely to belong to the loan accessed group, possessing a certificate of occupancy, having guarantor as collateral, salary on collateral, having land and building as collateral were found to have very high $\operatorname{EXP(B)~values~as~11.257,~10.222,~15.927,~}$ 10.443 and 10.496 respectively which predispose them to the high probability of belonging to the group with access to a loan. While private work as an occupation, primary and secondary education, loan amount, loan duration, previous default with EXP(B) values of 1.822, 15.422,4.349, 1.053, and 2.134 respectively present a high likelihood of belonging to women without access to the loan.

The implication of the foregoing is that women with increase income, working with the government (having regular income), and having landed related collateral for loans will most likely have access to a loan for their enterprises. This finding corroborates the works of Sanusi (2012) and Ifelumi \& Wosowei (2013) who asserted that the formal loan markets will always find some assets as surety for their loans. However, it is pertinent to note that women in the category stated above are few which indicate that majority of women entrepreneurs will still suffer lack of access to a loan in the formal loan markets in the study area. Hence, the need to make special arrangements that could facilitate women loan access in Nigeria like its counterpart in the advanced countries. 


\section{Conclusion}

The paper attempts to investigate the factors that affect women's access to a loan in the study area. The study adopted descriptive statistics, t-test statistics, and logistic regression analysis. the paper found that loan applicant's income, government work as an occupation, possession of tertiary education, marital status, possession of a certificate of occupancy as collateral, guarantee as collateral, salary as collateral, land, and building as collateral, and years of relationship with lending institution exact significant positive effects on women access to loan while factors, such as private work as an occupation, primary education, secondary education, loan amount, loan duration and previous history of loan default have a significant negative effect on women loan access. The result corroborates the findings of Ibrahim and Aliero (2012) where the authors also found that level of income, collateral requirements, educational attainment, and marital status have a significant positive influence on accessibility to loan among women, although, their work did not find government work as a form of occupation as having a significant positive influence on loan accessibility.

The findings regarding the likelihood of women with access to a loan or without access is very key to understanding the enormity of the challenges of women in accessing loan especially in areas of fulfilling collateral requirements of format loan service providers. It is pertinent to know that all the forms of collateral acceptable to lending institutions in the study area have a highly significant positive likelihood (going by their odds ratio). In other words, possession of any of these forms of collateral predisposes the applicant to loan access group, while failing to fulfil the requirement also predisposes such applicants into the non-loan access group. In this regard, most women will certainly be priced out of the loan markets. It is noteworthy that though women are increasingly cultivating the habit of saving their money in the bank, however, very many of them at the point of applying for loan fail to fulfil the requirements especially in the area of getting adequate security, hence, denial of financial service. Sanusi (2012) also opined that the traditions that forbid women ownership of land for which title could be used as collateral further complicates women access to formal loan service providers. World Bank (2014) noted that despite the growth of the financial sector in South Sahara Africa, the poor are found to be mostly excluded from the formal financial sector on account of their relatively low level of income and lack of assets which can be used as security for the loan. Authors have denied that the main ideology underlying the microfinance model is to enable the poor who are mostly excluded from the formal financial sector to have access to financial services to improve their likelihood leading to a reduction in poverty. The proliferation of microfinance banks has not largely improved women access to loans so much so that they also exclude the poor from the loan access due to lack of business history and collateral requirement.

Considering the practical implications of the study, the findings serve as inputs for decision makers/ policymakers, offers direction to lenders in the area of rebranding their products for an all-inclusive economic development.

While the findings of the study could be used in another environment, however, the findings of the current study are specifically applicable to the area of study, further study could involve larger data than what is used in the current study and could be replicated across countries.

\section{References}

i. Ahmad, S. Z., \& Muhammad Arif, A. M. (2015). Strengthening access to finance for women-owned SMEs in developing countries. Equality, Diversity and Inclusion: An International Journal, 34(7), 634-639.

ii. Amuta M. (2013). Engendering access to financial services in Nigeria. Available at http://dailypost.ng/2013/03/12/amuta-mathias-engendering-access-to-financial-services-in-nigeria/

iii. British Council, N. (2012). Improving the Lives of Girls and Women in Nigeria. Genderi n Nigeria Report. Issue policies Action. $2^{\text {nd }}$ Edition

iv. Bullough, A., Bullough, A., Moore, F., Moore, F., Kalafatoglu, T., \& Kalafatoglu, T. (2017). Research on women in international business and management: then, now, and next. Cross Cultural \& Strategic Management, 24(2), 211230.

v. Jackson C. and Pearson R. (eds.), Feminist Visions of Development: Gender Analysis and Policy, Routledge, London and New York

vi. Central Bank of Nigeria (2005):'Microfinance Policy, Regulatory and Supervisory Framework for Nigeria' Abuja, Nigeria

vii. Central Bank of Nigeria (2003), 'List of Licensed Banks in Nigeria', Annual Bulletin of the Central Bank of Nigeria

viii. Mhiche, E. (2020). The Contribution of Microcredit Programs on Economic Empowerment of Women Entrepreneurs in Tanzania: A case of Morogoro Municipal (Doctoral dissertation, Mzumbe University).

ix. Cheston, S., \& Kuhn, L. (2002). Empowering women through microfinance. Draft, Opportunity International. UNIFEM

x. Chinasa, W. E. (2015). Constraints to women entrepreneurs' access to microfinance in Bayelsa state, Nigeria. Research Journal of Finance and Accounting, 4(6), 6-13.

xi. Dalley-Harris, S. (2002). Pathways out of poverty. innovations in microfinance for the poorest families, (Ed.) Kumarian Press. Inc. USA.

xii. Dawson, V. C. W. (2016). Exploring Financial Inclusion for Smallholders: Promoting the Sustainable Development of Smallholder Aquaculture in Developing Countries (Doctoral dissertation).

xiii. De Haan, A. (2016). Enhancing the productivity of women-owned enterprises: the evidence on what works, and a research agenda. Department of Geography, University of Sheffield, Sheffield, UK

xiv. Demirgüç-Kunt, A., Beck, T., \& Honohan, P. (2008). Finance for all. Policies and Pitfalls in Expanding Access. World Bank, Washington, DC. 
xv. Ebdon, R., 1995, 'NGO Expansion and the Fight to Reach the Poor: Gender Implications of NGO Scaling-up in Bangladesh', IDS Bulletin, Vol. 26 No.3

xvi. FAO (2011),'Gender Equality and Development', UN Research Institute for Social Development

xvii. FAO (2013), 'Policy on Gender equality; attaining food security goals in agriculture and rural development', Food and Agriculture Organization of the United Nations, Rome.

xviii. Fay, M. \& Williams, L. (1993), 'Gender bias and the availability of business loans', Journal of Business Venturing, $8(4), 363-376$.

xix. GPFI, I. (2011). Strengthening Access to Finance for Women-Owned SMEs in Developing Countries. International Finance Corporation. Washington, DC.

xx. Hisrich, R. D., \& Brush, C. G. (1987). Women entrepreneurs: A longitudinal study. Frontiers of entrepreneurship research, 187(1), 566-578.

xxi. Ifelunini, I. A., \& Wasowei, E. C. (2013). Constraints to Women Entrepreneurs" Access to Microfinance in SouthSouth Nigeria. Research journal of Finance and Accounting, 4(6).

xxii. Korosteleva, J., \& Stępień-Baig, P. (2020). Climbing the poverty ladder: the role of entrepreneurship and gender in alleviating poverty in transition economies. Entrepreneurship \& Regional Development, 32(1-2), 197-220.

xxiii. Innocent, A.I\& Elizabeth C.W (2013), 'Constraints to Women Entrepreneurs' Access to Microfinance in SouthSouth Nigeria', Research journal of finance and accounting, Enugu, Nigeria.

xxiv. International Finance Corporation (2011), 'Strengthening access to finance for women-owned SMEs in developing countries', The World Bank group, Washington D.C.

xxv. Kabukuru, A. (2016). Analysis of challenges faced by women entrepreneurs in accessing finance in Kenya-a case of women entrepreneurs in Nairobi Central Business District (Doctoral dissertation, Strathmore University).

xxvi. Karim, L. (2008). Demystifying micro-credit, the Grameen Bank, NGOs, and neoliberalism in Bangladesh. Cultural Dynamics, 20(1), 5-29.

xxvii. Kulb, C., Hennink, M., Kiiti, N., \& Mutinda, J. (2016). How Does Microcredit Lead to Empowerment? A Case Study of the Vinya wa Aka Group in Kenya. Journal of International Development, 28(5), 715-732.

xxviii. Kushnir K \&Meilland T (2011), 'Mapping the legal gender gap in using property and building credit', Women, Business and the law, World Bank group, Washington DC.

xxix. Leach, F., \& Sitaram, S. (2002). Microfinance and women's empowerment: A lesson from India. Development in Practice, 12(5), 575-588.

xxx. Magaisa, G. M., \& Matipira, L. (2017). Small and medium enterprises development in Zimbabwe. Energy, 50, 000.

xxxi. Mayoux, L. (1998). Participatory Learning for Women's Empowerment in Micro-Finance Programmes: Negotiating Complexity, Conflict and Change. IDS bulletin, 29(4), 39-50.

xxxii. Mayoux, L. (1999). Questioning virtuous spirals: micro-finance and women's empowerment in Africa. Journal of international development, 11(7), 957.

xxxiii. Mayoux, L. (2000). From access to empowerment: Gender issues in micro-finance. NGO Women's Caucus Position Paper for CSD-8 (CSD).

xxxiv. Mayoux, L. (2002). Microfinance and women's empowerment: Rethinking 'best practice'. Women, Gender and Development in the Pacific: Key Issues, 57, 20.

xxxv. Mbiti, F. M., Mukulu, E., Mung'atu, J., \& Kyalo, D. (2015). The Influence of Access to Credit on Growth of WomenOwned Micro and Small Enterprises in Kitui County, Kenya. Public Policy and Administration, 3(1), 61-70.

xxxvi. Mthethwa, Z. P. (2016). The role of financial access in the success of small and medium enterprises in Swaziland (Doctoral dissertation).

xxxvii. Mukama, J. A. (2017). Contribution of women entrepreneurs on socio-economic development of Rwanda through Urwego opportunity bank (2011-2015) (Doctoral dissertation).

xxxviii. Ngozi G.I (2002), 'Women Entrepreneurship and Development: The Gendering of Microfinance in Nigeria', the 8th International Interdisciplinary Congress on Women, Makerere University, Kampala-Uganda

xxxix. Mwayi, A., Odindo, S. J., \& Odindo, D. O. (2015). Assessment of KAP Factors Influencing Access to Loans for Women SMIEs in Nyalenda. American Journal of Economics, Finance and Management. 1(5),430-438.

xl. Nwosu, E. O., Orji, A., Nnetu, V., \& Nwangwu, C. (2015). Is there Discrimination Against Women Entrepreneurs in Formal Credit Markets in Nigeria? Working paper, 2014-08, Partnership for economic policy.

xli. Rahman, A. (1999). Micro-credit initiatives for equitable and sustainable development: Who pays? World development, 27(1), 67-82.

xlii. Sabah, H. (2014). Women Entrepreneurs leading Social enterprises: HRM Challenges and Opportunities. National Conference on Entrepreneurship for Socio-economic development: Challenges and Opportunities - RV Institute of Management (4th July)

xliii. Sanusi, L. A. S. (2009). Assessment of current development in the Nigerian economy and the CBN policy action. BIS Review, 89.

xliv. Sanusi L.S (2012),'Increasing women's access to finance -challenges and opportunities', The Second African Women's Economic Summit, Lagos.

xlv. Stevenson L. \& St-Onge, A. (2005) 'Support for Growth-Oriented Women Entrepreneurs in Kenya, 'International Labor Organization, Nairobi, Kenya.

xlvi. Suzy C \& Lisa K (2011): 'Empowering women through microfinance' UNIFEM Publication,

xlvii. USAID (2000), 'Microenterprise development in a changing world', Agency for international development, USA. xlviii. World Bank (2012), 'Gender Equality and Development', World Bank Development Report, Washington, DC. 
xlix. World Bank (2014): 'Global financial development report; Financial inclusion', World Bank, Washington, DC.

l. World Bank Group (2013), 'Gender and Development; Credit and financial services', The World bank, Washington, DC.

li. Kabeer, N. (2020). Women's Empowerment and Economic Development: A Feminist Critique of Storytelling Practices in 'Randomista' Economics. Feminist Economics, 26(2), 1-26. 